\title{
LA ANTROPOFAGIA COMO RITO FINAL DE LA INFANCIA EN EL REGRESO DE EFRAÍN BARQUERO
}

\author{
Claudio Guerrero Valenzuela \\ Pontificia Universidad Católica de Chile \\ cmguerre@uc.cl
}

RESUMEN/ABSTRACT

Este artículo analiza las representaciones de infancia en el libro El regreso del poeta chileno de los años 50, Efraín Barquero. Se postula que en este poemario existe una disposición escénica que pone a un adulto devenido discursivamente en niño frente a su padre muerto, para llevar a cabo el rito de servírselo como alimento. Mediante este acto sacrificial de tipo antropofágico, el sujeto lírico logra clausurar su infancia y pasar plenamente a la adultez.

PALABRAS Clave: Barquero, infancia, antropofagia, padre, rito.

This paper sets out to investigate the representations of childhood in El regreso by the Chilean poet of the 50s, Efrain Barquero. We propose that in this poem there is a scenic disposition where an adult-represented a child-, standing opposite his dead father, is about to carry out the anthropofagical rite of eating him up. By means of this cannibalistic act, the lyrical persona manages to close his childhood and to go on fully into adulthood.

KEY WORDS: Barquero, Childhood, Cannibalism, Father, Ritual.

\section{LA INFANCIA EN LA TRAYECTORIA POÉTICA DE EFRAÍN BARQUERO}

El presente trabajo tiene como objetivo principal analizar la representación de la infancia en una obra medular dentro de la producción poética de Efraín 
Barquero $(1931)^{1}$ en la cual se clausura la infancia a través de una ceremonia ritual de tipo antropofágica. Se trata del poemario El regreso, publicado en 1961 en Santiago. Hasta la publicación de este libro, la poesía de Barquero se había caracterizado por una sólida construcción poética que se había inaugurado con La piedra del pueblo, en $1954^{2}$, y luego profundizado en La compañera (1956), Enjambre (1959) y El pan del hombre (1960). En estas primeras obras aparecen los elementos que pueblan toda su poesía, formando una reunión vital de elementos primordiales dispuestos sobre una mesa: la mesa de la tierra. Allí aparecen el pan, la piedra, el agua y la tierra en conjunción dialógica con los trabajos ancestrales del ser humano, casi en un sentido antropológico: el trabajo de la cocina, la vasija, el tejido, el fogón. Estos elementos confluyen en un cosmos que intenta fundarse y refundarse en el fuego del hogar, el vientre de la amada, la naturaleza circundante, envolviendo lo privado y lo social en una relación entretejida por el trabajo cotidiano de esa construcción y haciendo de la poesía de Barquero un espacio de íntima comunión con la palabra y con un reconocerse en el otro, en lo otro.

En estos primeros poemarios, la infancia aparece tímidamente como recuerdo o evocación de una noche estrellada en el río Maule, una mujer desnuda y solitaria tendida en la playa, el rostro del abuelo, la mano de la madre; en fin, una serie de olores, sonidos e imágenes que conforman una cierta sensorialidad. Sin embargo, es a partir de su sexto libro, El regreso, cuando el tema de la infancia adquiere un cariz especial que hace que requiera de su atención. Con este texto se producen en la obra del poeta dos movimientos "que se extienden en direcciones opuestas para reencontrarse más adelante: por un lado, un despliegue metafísico y arquetípico que se detiene en el ciclo de la vida como regeneración natural y, por otro, un arraigo en el mundo del niño representado ahora a través del lenguaje infantil y el juego" (Nómez, "En torno"12-13). Esto último se da con la recurrencia a la canción popular, a lo musical en el poema y a imágenes graciosas de recreación y estimulación de la curiosidad infantil en sus siguientes libros, Maula (1962) y Poemas infantiles (1965). En estos dos libros, la infancia se recrea como un espacio

\footnotetext{
Barahona.

Nacido en Piedra Blanca, Curicó, Región del Maule. Su nombre civil es Sergio Efraín

2 Dentro de su bibliografía, los estudiosos consignan la publicación de Árbol marino en 1950. Sin embargo, no es considerada su primera obra sino un prospecto de lo que luego sería La compañera (Nómez "En torno a..." 8).
} 
de ternura y de acogimiento por parte de un adulto que desea acompañar al niño en la etapa donde todo es curiosidad y aprendizaje lúdico. Aquí, más que existir la sensación de una vivencia concreta, se da la proposición de figuras, escenas o estampas de experiencias infantiles prototípicas. Estas se vuelven universales (se eternizan) al ser realizables en cualquier tiempo o lugar. Tras esta trilogía de libros de infancia, Barquero publica El viento de los reinos (1967), Epifanías (1970), Arte de vida (1971), El poema negro de Chile y Bandos marciales (ambos de 1974). A continuación, tras un largo silencio que coincide con el exilio, Barquero vuelve a nuestro país y publica tres libros en un mismo año, en 1992: A deshora, Mujeres de oscuro y El viejo y el niño. Va a ser con la publicación de Mujeres de oscuro donde nuevamente aparece la visión de la infancia, "esa edad misteriosa que vivimos antes" (Barquero, Antología 270) como tema recurrente, esta vez mediante la impostura de una voz que actualiza las visiones de su hogar infantil habitado por una serie de personajes adultos que llaman su atención. Con El viejo y el niño, en tanto, hace hablar nuevamente a un infante, como en El regreso, esta vez con un anciano. Ambos personajes se reconocen a sí mismos como en un espejo, como símbolos de las etapas de la vida en donde la ingenuidad y el juego se pierden en un determinado momento y se quiere recuperar. Esta vuelta hacia los orígenes representa la posibilidad de completar un círculo inconcluso. La producción posterior de Barquero contemplará las obras La mesa de la tierra (1998), Antología (2000) ${ }^{3}$, El poema en el poema (2004), El pan y el vino (2008) y diversas traducciones a otros idiomas. En 2008 es galardonado con el Premio Nacional de Literatura.

\section{LA RECEPCIÓN CRÍTICA}

La crítica especializada sobre la obra de Efraín Barquero es escasa y se basa fundamentalmente en referencias breves (artículos, reseñas, notas introductorias) que no profundizan lo suficiente sobre su obra y algunas tesis universitarias como las de Navarrete (2000), Matteo (2001) y Davison (2005). Para Navarrete, el poeta maulino opera bajo una contradicción filosófica: querer establecer un tipo de antropología trascendental recurriendo a la materia. Sin embargo, logra salvar tal paradoja mediante la construcción de

3 Una muy buena edición que contempla gran parte de su obra y en donde se reproduce en forma íntegra El regreso y El viejo y el niño. 
un "cosmos material" que articula, dialécticamente, sus partes contrarias. De esta manera, su obra, y en especial El regreso, es la presentación formal de una dinámica dialéctica que pone en entredicho al hijo con el padre, al ser humano con los frutos, al ser humano con la tierra, $\mathrm{y}$, finalmente, a la vida con la muerte (Navarrete 93). La síntesis de estos vaivenes dialécticos termina fundiendo vida y muerte: su fin en el origen. De este modo, la existencia es considerada en la obra de Barquero como un eterno retorno hacia nosotros mismos, como búsqueda continua de la respuesta ante la pregunta por la verdadera identidad del ser (Navarrete 132). Matteo señala que en El regreso se condensan y se sintetizan todos los temas de su poesía, mundo que está en permanente construcción. En efecto, esta obra es la culminación de una genealogía poética de tipo fundacional que lo posiciona en el mundo. Esto significa, "por un lado, buscar una herencia y por otro, buscar y o (re)crear un mundo al cual pertenecer" (11). Davison, por último, asegura que Barquero trabaja, desde una óptica fenomenológica, una poética del espacio centrada fundamentalmente en la casa, la que es configurada a lo largo de toda su obra como un espacio de celebración, en el sentido de indagación y (re)conocimiento de los mitos, símbolos e imágenes originarios. Señala el autor que en la obra de Barquero "la casa es un especie de teatro sagrado, un microcosmos especial donde los moradores realizan simbólicas celebraciones de diversa índole" (20). En este espacio "sagrado", la mesa se constituye como centro, un espacio lleno de significaciones de orden trascendente. Llama la atención, sin embargo, que pese a su acertada perspectiva no haya incluido en su análisis ningún poema de El regreso.

\section{LOS GESTOS RITUALES DE EL REGRESO}

Sin duda El regreso se erige como un punto de inflexión dentro de la obra del poeta, no solo por su temática renovadora sino que también por su estructura y presentación formal. Esta obra está compuesta de 21 textos breves distribuidos en poco más de noventa páginas ${ }^{4}$ y se destacan en él los grandes espacios en blanco entre poemas y, sobre todo, entre versos (agrupados por lo general de dos en dos) que hacen de este poemario una expresión de insterticios o

4 Para el presente trabajo se ha utilizado la primera edición, que no cuenta con páginas numeradas. Se les ha asignado a cada poema un número de página siguiendo el modo usual de hacerlo. 
formas de lo no dicho, en el que el silencio juega un rol fundamental ${ }^{5}$. El regreso representa en gran parte de sus versos el diálogo entre un niño y su padre muerto que viene a visitar a su hijo a su casa. Mediante recursos lingüísticos como guiones, comillas y una voz predominante en los poemas (la voz del hijo ${ }^{6}$ ), podemos reconocer la alternancia de hablas de uno y otro, y los pensamientos "en voz alta" del yo lírico. El padre se ve a sí mismo en su lecho de muerte, rodeado de gente que apenas reconoce: su mujer, sus hermanos, sus cuñados. La escena, en palabras del propio autor ${ }^{7}$, corresponde a un rito campesino antiguo: al morir, el padre es puesto sobre la mesa, es vestido y lavado, y allí es velado hasta su entierro. El hijo mayor, de acuerdo a la tradición, es el encargado de llevar a cabo este proceso. Es evidente, aquí, la progresión de acciones que involucran al sujeto lírico y que confirman su participación en un ritual de tipo fúnebre: el sujeto porta una ofrenda en sus manos (poema I), se inclina dos veces sobre su padre (poema II), parte el pan, come y bebe (poema III), abre puertas en busca de una sábana (poema IV), da de comer al padre (poema V), el padre está rodeado de familiares y su cuerpo desnudo sobre sábanas blancas (poema VII), lava las manos de su padre, limpia su rostro, ordena sábanas como mortajas (poema VIII), llena la mesa de frutos (poema XIII), derrama agua en las manos de su padre (poema XVIII), se sirve a su padre en la cena (poema XXI). Destacamos, entonces, la presencia de una disposición escénica de los poemas que nos habla del desarrollo de un ritual en donde se aprecia una función dramática ceremonial. Tanto las acciones del sujeto lírico -el gesto formalizado-como los silencios entre poemas y entre versos ayudan a conformar esa atmósfera.

Pero, ¿cuáles son las características propias de un rito? Este, señala Octavio Paz, es una actualización de un pasado inmemorial, de un pasado que está más allá de todos los pasados, en el origen del origen (20). Pero no solo tiene esta dimensión temporal actualizadora de un eterno pasado

5 Myrna Solotorevsky señala que los espacios intersticiales son esferas por sí mismas significativas (espacios silenciosos) ubicadas entre otras esferas igualmente significativas (los espacios escritos) (18). De acuerdo a su categorización, El regreso bien podría situarse dentro de una estética de la fragmentación, es decir, donde los insterticios refuerzan especularmente la fragmentación del texto.

6 Difícilmente podemos hablar aquí, como señala Navarrete, de un diálogo en sentido estricto (129).

7 En entrevista con Cristián Warnken para el programa La belleza del pensar, del canal de televisión ARTV. 
ni se preocupa únicamente de defenderse ante los cambios del presente. También tiene una envoltura. En efecto, el ritual, como señala Susanne Langer, es "el reflejo más primitivo de pensamiento serio, algo así como un lento sedimento de la imaginativa intelección humana en la esencia de la vida. Por tal motivo resulta intrínsicamente solemne" (184). Su finalidad no es tanto práctica (hacer llover, por ejemplo), sino más bien religiosa: tiene relación con la sanación de los miedos de los seres humanos. Su forma más extendida es el sacramento: una acción familiar y doméstica, como lavar, comer, beber (Langer 186). Es el tipo de ritual que aparece en el poemario de Barquero aunque con otra perspectiva: la comida de otro ser humano. El canibalismo fue una práctica extendida en varios pueblos americanos antes de que, en el periodo de la conquista española, los religiosos se preocuparan de su proscripción. Entre los diferentes tipos de antropofagia, de acuerdo a las finalidades de sus prácticas (básicamente por necesidad alimentaria, en un caso, o para adueñarse del espíritu valiente del enemigo, en otro caso), hay una que mantiene un denominador común: la antropofagia que se da a cabo de modo ritual cuando se muere uno de los parientes. La ceremonia consistía en incinerar sus cuerpos y beber sus cenizas y huesos molidos en un brebaje mezclado con bebidas de diferente tipo. De acuerdo a esto, se regenerarían las fuerzas vitales del grupo familiar, permitiendo conservar en ellos las cualidades del fallecido (Azócar 110). Apreciamos, en Barquero, como en los antiguos primitivos americanos, un canibalismo de este tipo para alimentar a los miembros del grupo familiar ${ }^{8}$.

En El regreso el rito se inicia en el primer verso de manera esclarecedora con un sujeto lírico que declara: "Yo soy el portador" (9), es decir, el que lleva o trae algo de una parte a otra, en este caso, el aromo ("aserrín inservible") que se deshace en sus manos. Encontramos de entrada, entonces, la primera clave del poemario. El portador "es el sujeto perteneciente al mundo sacro o mítico que cumple una misión muy delicada: sostener y transportar el principal símbolo sagrado, sin el cual no se puede llevar a efecto el rito" (Navarrete 115). El florecimiento del aromo, en tanto, prefigura la primavera. Sin embargo, aquí se trae semilla vieja, incapaz de dar fruto. Su símbolo

8 Es impensable, también, no pensar en el ritual de tipo cristiano de comer y beber de manera simbólica el cuerpo y la sangre de Cristo, hecho que cumple una función renovadora similar, en este caso, como recordatorio del sacrificio realizado por él en pos de la humanidad. 
sagrado es, en verdad, su propio padre muerto que viene consigo, como sombra. Por eso, cuando abra la puerta "entrará la sombra conmigo" (9). Es este sujeto lírico el encargado de sacrificar a su padre, comunicarle su muerte y ayudarlo a morir. En todo sacrificio, el sacrificado es la sustitución del Dios (el Padre) y su función es religiosa: recordar que no hay vida absoluta sin muerte como también es "ante todo oblación, ofrenda", es decir, una renuncia que implica una entrega y un "sui-cidio" (Maldonado 48-49) 9 . En el caso de Barquero, hablaremos de una muerte real, la del padre, pero que ha vuelto para ser sacrificado en función de una muerte metafórica: la de la infancia. Dice el sujeto lírico en el mismo poema I en relación con el encuentro con el padre:

Cuando estreche su mano, será su corazón lo que ahogue entre las mías.

Estará esperándome, y un poco cansado de mi tardanza.

Regreso tarde, hombre dormido, golpeo en la puerta de tu casa para que despiertes o duermas más profundamente (10).

De este modo, se da inicio a la ceremonia ritual, que luego es reafirmada trascendentalmente en el poema III:

-Padre, siempre cuando parta el pan, estaré

tratando de comprender este momento (15).

Postulamos que desde un principio la infancia es representada a través de un sujeto lírico que realiza la impostura de un adulto que se hace pasar por niño (dice en el poema IV: "En una noche espaciosa como la casa de la / infancia -llena de habitaciones y visitantes / imprevistos- yo abro cada puerta" (17)), para dar muerte a su padre (en el poema IX dice: “-Padre, te enseñaré la muerte" (39)) y así poder liberarse completamente de lo que él representa. Por eso, el padre le dice en el mismo poema IX:

-Hijo, te enseñaré a vivir con mi ausencia.

"Y aprenderás el secreto de tu propio cuerpo (39).

9 La cursiva en 'oblación' y la separación de la palabra 'suicidio' son del original. Entendemos que el autor hace la separación de la palabra para enfatizar el carácter sacrificial de toda ofrenda. 
El sujeto lírico realiza un viaje en doble sentido: vuelve hacia su infancia y acompaña a su padre muerto en el inicio de su descenso hacia el mundo de los muertos. Como sabemos, este tópico posee una vasta tradición lírica a partir del viaje de Odiseo al infierno, en la rapsodia undécima de la Odisea (s. VIII a.c.). Las acciones que realiza allí el héroe son de tipo sacerdotales: "excavar una fosa, hacer libaciones, espolvorear con flor de harina las ofrendas, implorar de rodillas a las almas de los difuntos" (Grammatico 67). Es decir, debe llevar a cabo un ritual. No parece casual, por otro lado, la relación que existe entre el tópico que el poeta actualiza en su obra con el seudónimo que escogió mucho antes para darse a conocer como poeta: Barquero: Caronte: el transportador de almas desde el mundo de los vivos hasta el mundo de los muertos. Pero el acompañamiento al padre en su muerte, "vivir la muerte", significa también estar en condiciones de asumir su lugar. En este sentido, conocida es la teoría psicoanalítica del parricidio o asesinato del padre primordial. Freud en su ensayo "El retorno del totemismo en la infancia" incluido en Tótem y tabú (1913), afirma que el animal totémico que es sacrificado y devorado en los oficios religiosos corresponde a una sustitución del padre, a su vez, sustituto del dios. El banquete totémico es la representación, entonces, de la matanza y devoramiento del padre por parte de los hermanos para dar fin a la horda paterna, esto es, el reservarse para sí a todas las hembras y expulsar a los hijos varones cuando crecen (143). Al devorarlo, consuman su identificación con él, apropiándose de una parte de su fuerza y compartiendo la culpa por el crimen perpetrado en común, hecho que supone la liberación del arrepentimiento. Este banquete totémico constituye "la primera fiesta de la humanidad" (144) y es lo que hallamos en este poemario también, como ritual actualizador, para así erigirse como individuo adulto. La forma escogida - no podía ser otra- es devorándoselo: el sujeto se lo sirve en la mesa.

En este encuentro, entonces, padre e hijo se reúnen como en un rito sacrificial de carácter simbólico, sagrado y renovador, que, a decir del propio autor $^{10}$, tiene una correspondencia en el teatro del escritor belga Maurice Maeterlinck ${ }^{11}$, dramatismo que carga la obra poética de una representatividad

10 En entrevista citada.

11 Maeterlinck es autor de Pelleas y Melisande (1892) y El pájaro azul (1908), entre otras obras teatrales. En El pájaro azul se desarrolla la historia de un niño que quiere ayudar a su vecina enferma. Para tal efecto, un hada le ha pedido que encuentre el pájaro azul que la llevará a sanarse. El niño recorre junto a su hermana diversos espacios mágicos: El Palacio 
escénica desde principio a fin y que hace que en Barquero todos los elementos adquieran un valor más allá de la cosa misma justo allí donde funda lo sacramental cotidiano. En este contexto, apreciamos que la disposición escénica, en un momento determinado, se vuelve de una visualidad y esteticismo únicos, como aparece en el poema VIII:

Yo le sirvo la más larga de todas las comidas.

Lavo sus manos sobre una tierra oscura que las hace más pálidas y sobrenaturales.

Limpio su rostro que quiere desprenderse del cuerpo.

Ordeno las sábanas como un traje demasiado grande.

Es evidente que aquí el rito alude directamente a momentos que pertenecen a la tradición cristiana y que asociamos a la pasión de Cristo y su resurrección: el lavar las manos (como el lavado de pies en La última cena), limpiar el rostro (escena del Calvario de Cristo; manto sagrado), ordenar las sábanas (la mortaja de la tumba de Cristo). Como precisa Navarrete, "las mortajas que han sido ordenadas son aquellas que ya han sido utilizadas y puestas en desorden: las mortajas de Lázaro resucitado y de Jesús resucitado y resucitador" (121). Como lo intentaron hacer los poetas simbolistas, existe aquí una preocupación por indagar y develar el sentido misterioso de la existencia en la realización de lo sagrado, pero creemos que el sujeto lírico no se queda solamente en ese lugar: hay en él una acción movilizadora que tiene estrecha relación con el fin que desea darle a una etapa de su vida. En este sentido, la metafórica resurrección del padre se escenifica en función de otra acción aún más importante y que tiene que ver con el rol sacrificial del sujeto lírico en tanto portador del rito. En efecto, en El regreso la visita del progenitor genera una muerte metafórica en el sujeto lírico, quien al alimentarse de su padre da cierre a un ciclo vital: el fin de la infancia.

de la Noche, Los Jardines de las Dichas, El Reino del Porvenir, entre otros lugares, y lleva consigo un gran Diamante que hace ver el alma de las cosas: el pan, el vino, la pimienta, el azúcar, el Pasado y el Porvenir. 
El rito representa, de esta manera, una dialéctica entre vida y muerte, que no se resuelve para un lado u otro, sino que se articula en una especial ambigüedad que queda, en varios poemas, abierta. Por ejemplo, en el poema $\mathrm{X}$, la casa familiar se asimila a una tumba, de acuerdo a la voz del padre: "Veo a través de ti la casa que construimos / con tu madre" y más abajo señala: "Un muro de adobe nos detuvo". Luego: "Estábamos bajo un cielo de tierra oscurecida" (43-44). Es decir, la casa es fuente de vida y de celebración, pero también de muerte. En el poema XI, sin embargo, constatamos un segundo momento clave dentro del rito escenificado en el poemario, y es cuando el hijo dice a su padre: "Es tu hora, la única hora que conocen los amantes / y las criaturas que van a nacer" (47). Es la hora de la muerte y la resurrección, la hora en que el hijo conduce a su padre por una puerta: "Esta es tu mano. Por aquí está la puerta". (48), y la hora en que el hijo debe volver a nacer. Es decir, no solo el momento de encontrar una síntesis a la dialéctica entre vida y muerte, sino que también la hora de crecer y de dejar de ser un niño, como se confirma en el poema siguiente, el número XII:

Hombre oscuro, no sé si pequeño, cobijándome entre tus piernas poderosas, como un animalillo asustado, he sentido el imperativo de vivir y crecer.

No recuerdo si al tender tus manos hacia mí, al tentarlas y conocer su forma, he concebido la estructura del mundo.

Porque escalé tus brazos en un supremo acto de aprendizaje de las cosas.

Y tú me sostuviste junto al árbol cargado de frutos, o sobre el mar que nos quería incorporar a su sustancia.

En este poema, el niño (representado como un "animalillo asustado") evidencia el imperativo de vivir y crecer: hacerse hombre, despojarse de su padre. Como Iván, el personaje apasionado de Los hermanos Karamazov de Fiodor Dostoievski, ha llegado el momento de "querer matar" al padre. Este sentimiento expresa la necesidad de despojarse de una competencia amenazante para convertirse, en definitiva, a una identidad propia que deja atrás la carga del pasado filial. En esta novela, el joven Iván racionaliza con 
la idea de que todos, alguna vez, hemos deseado deshacernos de nuestro padre. Enajenado por la culpa al ver materializada su opción intelectual, con un fajo de dinero en su mano, Iván lo reafirma trágicamente ante los jueces que acusan a su hermano Dmitri de matar a su padre:

-Lo recibí ayer de Smerdiákov, del asesino. Estuve en su casa antes de que se ahorcara. Fue él quien mató a mi padre, y no mi hermano. Fue él quien lo mató, y yo le enseñé a matar... ¿Quién no desea la muerte de su padre?

- ¿Está usted en su juicio? -soltó el presidente, a pesar suyo.

-Esa es la cuestión, que estoy en mi juicio... y en un vil juicio, exactamente igual que usted y que todos esos... j carotas! -de pronto se volvió hacia el público-- Han matado al padre y hacen como si estuvieran asustados -rechinó con maligno desdén-. Unos con otros fingen. ¡Embusteros! Todos desean la muerte del padre. Una alimaña se come a otra alimaña... De no haber parricidio, todos se enojarían y volverían furiosos a sus casas... (993)

Como deseo natural, el sujeto lírico ya tiene conciencia de que ha llegado el momento de dejar atrás a su padre. No resulta extraño, entonces, la relación con esta novela que inaugura el tema del parricidio en la obra de Freud ("Dostoievski y el parricidio"):

La relación del niño con su padre es una relación ambivalente. Además del odio que quisiera suprimir al padre como un enfadoso rival, existe, regularmente, cierta magnitud de cariño hacia él. Ambas actitudes llevan, conjuntamente, a la identificación con el padre. El sujeto quisiera hallarse en el lugar del padre porque lo admira; quisiera ser como él y quisiera, al mismo tiempo, suprimirlo. Ahora bien: toda esta evolución tropieza con un poderoso obstáculo. En un momento dado, el niño llega a comprender que la tentativa de suprimir al padre como a un rival sería castigada por aquel con la castración. Y así, por miedo a la castración, esto es, por interés de conservar su virilidad, abandona el deseo de poseer a la madre y suprimir al padre. En cuanto tal deseo permanece conservado en lo inconsciente constituye la base del sentimiento de culpabilidad. Todos estos son, a nuestro juicio, procesos normales, el destino normal del llamado complejo de Edipo (220).

Podemos aseverar que el tema del parricidio en Barquero se presenta ritualizado en el marco de una solemnidad que expurga toda culpa e incluso 
la hace desaparecer en la armonía que se produce a la hora de reunirse en torno a la mesa y servirse al padre. Recordamos, por ejemplo, que con la muerte del padre en la obra de Barquero predomina un tono sereno y ambiguo, que lo aleja por cierto de la culpabilidad que sienten los personajes de Dostoievski. En este sentido, volviendo al poema XII, el sujeto reconoce en el padre el orden simbólico del poder que posee en cuanto centro del mundo, pero también lo relativiza ("No recuerdo si al tender tus manos hacia mí, / al tentarlas ${ }^{12}$ y conocer su forma, he concebido / la estructura del mundo" (51)). Esto hace que tenga que escalarlo "en un supremo acto / de aprendizaje de las cosas" (52), es decir, el sujeto que se está haciendo hombre reconoce el regalo de todo lo que se aprende del padre, por eso su árbol es uno que está "cargado de frutos", pero este árbol también, literalmente, se escala, como el tótem sagrado, símbolo de la divinidad de las sociedades tradicionales. Basta con recordar, por ejemplo, la imagen del rewe en la sociedad mapuche: árbol con forma de escalera en cuya cima se representa un rostro humano. Resulta interesante constatar aquí que el tótem termina siendo un refugio y salvación, que construye al ser y evita su disolución: el sujeto lírico es sostenido por el padre, ya sea junto al árbol o "sobre el mar que nos quería / incorporar a su sustancia" (52), es decir, la muerte.

El padre, de "piernas poderosas" y al cual se escala para llegar a ser como él, es representado en este poemario bajo la figura del árbol. La simbología del árbol tiene su origen en el instinto de "agarrarse a", esto es, constituye el actuar fundamental del ser humano y está dirigido fundamentalmente a la madre. En tanto instinto filial, toda persona, objeto o cosa a la cual el ser humano se aferre o se agarre constituye una "madre", un sustituto de la madre perdida (Marchant 27). Si aceptáramos esta interpretación, entonces, estaríamos ante un sujeto lírico que relativiza la figura de sus padres, configurándose no solo como un huérfano de padre y madre, sino que de padre y madre juntos, vistos como la misma cosa. Sujeto huérfano que no solo busca devorar a su padre, sino que también con él acarrear a su madre. Sin embargo, el objeto de búsqueda está, de antemano, perdido: el "aferrarse a" es siempre un acto inalcanzable. Por eso, el sujeto de estos poemas hace que el árbol que antes se podía escalar, pronto se vuelva tendido. En ese paso del padre erguido versus al padre tumbado, está el punto de inflexión

12 Nótese el verbo escogido por Barquero, más allá de la simple aliteración que se produce al asociarlo con el verbo tender: el tentar también tiene que ver con el deseo. 
en que el niño se da cuenta de que ya no puede aferrarse a nada, por lo tanto solo queda deshacerse de él para completar su acto: "matarlo", y, con eso, terminar el proceso de hacerse adulto. El padre-árbol tumbado, en el poema XIII, le pide entonces al hijo que llene su lecho con las frutas de la estación. Pero también le pide "aromo hasta palidecer, hasta / cubrir completamente mi cuerpo" (56), para que en su reemplazo nazca otro árbol: el hijo que toma su lugar. Recordemos que el aromo o acacia es la especie arbórea más resistente a las condiciones de suelo y humedad, y la primera especie vegetal que florece en invierno. Podríamos apreciar, entonces, su capacidad de fertilidad y su condición regenerativa.

\section{EL CIERRE DE LA INFANCIA}

La función dramática de este poemario hace que el rito poco a poco vaya adquiriendo mayor emotividad, sobre todo a partir del poema XIV cuando se constata que "toda nuestra casa se ha reducido a esta pieza" (59). Apuntamos: la tumba. Este cuarto, a su vez, es ahora de grandes paredes con una puerta que es "la puerta del mar" (59). Recordemos: el mar, "que es el morir" (Manrique) $)^{13}$. La mesa, por último, se llena de carnes y frutos, "como la tierra en el otoño" (59), o sea, en el tiempo de la cosecha. Esta remodelación de la habitación muestra el proceso de transformación que vive el propio sujeto, que todo lo ve con otros ojos. Pero también revela que la lucha entre vida y muerte se sigue librando, en una antítesis aún no resuelta. La abundancia, a su vez, genera en él un estado de satisfacción, porque es producto del trabajo campesino, esforzado y laborioso, de cosecha y recolección. Pareciera, entonces, que estuvieran dadas las condiciones para comenzar a realizar el banquete totémico, aunque vuelve a aparecer en el poema XV la amenaza y el temor ante el padre que le dice:

-Hijo, cuánto has tardado - me ha dichoadelantando sus manos en la actitud de comer (63).

El hijo ha tardado bastante en tomar la decisión de ser adulto, no solo en volver a él. En esta intensificación semántica apreciamos la idea de una decisión

13 De acuerdo a la tradición instaurada en el s. XV por Jorge Manrique en sus Coplas por la muerte de su padre. 
postergada por temor ("Y yo no he buscado su rostro para leer lo / que he temido siempre" (63)) y porque la "extraña vida de sus manos" genera en él repulsión y turbación. Es la amenaza de castración y el miedo al castigo del cual hablábamos antes por las consecuencias culposas de transgredir la ley. Luego, constatamos en el poema XVII la actualización de la parábola del hijo pródigo, cuando el hijo le entrega al padre sus ofrendas: las flores $\mathrm{y}$ frutos de la tierra, la miel de la última cosecha y el cordero de las últimas crías. Al tratarse de elementos recientes, como en todo ritual, le otorga a los objetos ofrendados un valor de pureza inigualable. Y recordemos que en la tradición occidental, el cordero es símbolo de sacrificio. El padre, en tanto, algo ansioso, le responde:

-Mostradme mejor al hombre que trajo estos presentes.

"Él es el único que puede calmar mi sed y mi hambre.

-¡Es un niño el que ha venido! (72)

Como en la parábola bíblica, el que vuelve viene carenciado y arrepentido, aunque con una nueva visión de las cosas. Aquí, el hijo vuelve como un niño, disminuido y temeroso (su padre es el único que puede calmar su sed: en la tradición cristiana, sed metafísica), pero con saberes nuevos, cargado de frutos. Y al igual que en la parábola bíblica, su regreso genera el banquete. Ahora bien, el hecho de que sea un niño el que haya venido, hace que él mismo sea una ofrenda también: el que va ofrecer su vida a su padre, como Jesús a Dios. En este contexto de sacralidad, en medio de la teatralidad ritual de la que hablábamos anteriormente, el sujeto (devenido en niño) (re)conoce la materialidad de los elementos y adquiere conciencia de ellos, tal como aparece en el poema XVIII:

Al fondo, y como sentado a la cabecera de una larga mesa, mi padre me pide que le derrame agua entre las manos.

Agua recién sacada de la noria, con mis rodillas apoyadas en la tierra y mi cuerpo inclinado en la boca del pozo.

Oscuro líquido que se va aclarando al llegar arriba en mi pesado balde. 
Agua ausente y fría que, una vez impregnados el rostro y las manos de mi padre, vuelve a su insondable vida de las profundidades (75-76).

En este reconocimiento de las cosas (tan propio del campo, en donde la naturaleza está hecha para ser cogida y apreciada), el niño también adquiere conciencia de la muerte: la "insondable vida de las profundidades" (76). También aprende que los elementos cósmicos cumplen una función para la conservación de la vida. En la impostura de una inocencia infantil, sin embargo, aún todo pareciera ser un juego, por lo que la imagen del niño junto a su padre se vuelve de una trágica ternura, en el poema XX:

Pero hay un niño que juega con los muertos.

Él ha recogido frutos que pone junto al gran desgano.

Él ha traído restos de viejas ropas y algunas herramientas.

Él se ha sentado a los pies de la puerta, sellada por los hombres.

El niño juega en esos brazos como en un árbol donde todavía quedan frutas.

Mira esos ojos que le devuelven no sé qué extraño mar azul donde juegan otros niños.

Y sonríe al descubrir por fin las manos, colocadas con pueril gravedad sobre el pecho. (83-84)

Llama la atención que el poema empieza con la conjunción adversativa "pero", lo que hace suponer que lo anterior se restringe. De ser así, lo que se propone dejar en claro el sujeto lírico es que el niño ha optado, por su voluntad, jugar con los muertos trayendo cosas llenas de vida: él ha recogido los frutos, él ha traído ropas viejas (cargadas de memoria) y herramientas (objetos de trabajo, por extensión, de creación de vida), él se ha sentado junto a la tumba (la puerta "sellada por los hombres" (84)). En otras palabras, lo que se destaca es que ha sido una iniciativa personal de querer sentarse junto al padre muerto y jugar con él. En ese juego de "pueril gravedad", como señala el hablante, encontramos un punto cúlmine del rito que se cierra por 
completo al entroncarse con el último poema del libro, el XXI, en cuya primera parte dice:

Padre, no pensé que un día al sentarnos a la mesa, estarías tú extendido como la más copiosa de las cenas.

Y serías tú mismo el dispensador de tu tierra más oscura.

No pensé que al reunirnos una última vez, tú crecerías de ti mismo más arriba que nosotros

Notamos cómo resuena el susurro constante de un sonido $(/ \mathrm{s} /)$ que remite a la siesta y el silencio, al sueño y la muerte. Podemos apreciar, también, cómo el hijo valora el último encuentro, al constatar que el padre vuelve a crecer (o al revés: el hijo vuelve a ser niño), de modo de reconocer en él la figura poderosa, el cual da cobijo y provoca temor a la vez. A continuación, el poema-libro finaliza con las siguientes estrofas:

Como lentos y cansados sembradores, en la gran mesa de la tierra, todos somos a la vez comensales y extraños frutos de los dioses.

Parecemos comer, y que alguien nos devora.

Parecemos coger algo en nuestras manos, y es la boca de la tierra la que se abre ante nosotros.

Habría que pensar en las semillas, en sus granos petrificados y secretos.

Habría que pensar en el instante de precipitarlas. (88)

El sujeto lírico devenido en niño toma conciencia de la finitud del ser humano al remitir en voz alta que en el banquete totémico no solo es él el que está devorando a su padre, sino que son "todos". En su calidad de portador se erige como el representante de la especie. Pero, a la vez, él también será devorado casi al mismo tiempo en que está comiendo. Inevitable es la alusión al mito 
griego de Cronos (Saturno romano), quien se devora a sus hijos por temor a ser destronado. Francisco de Goya, lo retrata terriblemente en uno de sus cuadros. Cronos, a su vez, es el tiempo que alimenta (lo nutricional del padre), pero también el que degrada (mata). En esta disputa entre el tiempo que alimenta y el tiempo que devora, pareciera que el factor nutritivo del tiempo termina venciendo al factor degradante, al revés de lo que sucede, por ejemplo, en la poesía de Jorge Teillier, compañero de generación. Hay también aquí otro paralelo mítico que sirve de sustrato al poema: los ritos sagrados de Eleusis en la antigua Grecia, "en donde el hombre representado por el fruto (Trigo), muere y queda sembrado en la tierra donde aflora como verdad y como recuerdo" (Matteo 33). Pareciera que por esta correspondencia simbolista, entonces, en esta comunión de padre, hijo, tierra y frutos, las semillas, las que luego se convierten en frutos, en hijos, son "granos petrificados y secretos". Sin embargo, el último par de versos son abiertos y polisémicos: ¿si habría que pensar en el instante de precipitarlas es porque luego se vuelven comensales y frutos a la vez? ¿Es porque así comenzaría un nuevo ciclo vital? ¿O porque hay algo de rencor doloroso en el proceso? Pareciera que el sujeto lírico quisiera detenerse un momento y respirar, darle la culminación adecuada al rito que ha llevado a cabo. Con esta proposición se cierra, entonces, el rito y el sujeto lírico ha quedado "libre": ha dejado de ser niño, ha matado al padre, después pensará en la idea de convertirse él mismo en un padre: "el último poema plantea una doble significación, por un lado una idea antropofágica, en donde el padre nutre de su experiencia al hijo para reordenar las cosas del mundo y, por otro, el verdadero rol del hablante como hijo y padre en el mundo, para asegurar su continuidad y su trascendencia como una nueva semilla" (Matteo 35). Junto con esta idea ${ }^{14}$, creemos que el sentido del texto, a nuestro parecer, tiene un profundo diálogo con el poema El sol es la única semilla (1948), del poeta de Lebu, Gonzalo Rojas, en donde dice:

Tú y yo somos dos tablas que alguien cortó en el bosque a un árbol milenario.

14 Debemos al estudio de Matteo la intuición de una lectura antropofágica. Sin embargo, su análisis se detiene en el mero plano de la enunciación y no desarrolla qué entiende por esa "idea antropofágica". Este trabajo, creemos, termina por dar una significación a esa lectura de El regreso en confluencia con el fin de la infancia. 


\section{Pero, ¿quién plantó ese árbol \\ para que de él saliéramos \\ y en el nos encerráramos? (60)}

El poema finaliza con la estrofa inicial y sus dos últimos versos: "Pero el sol / es la única semilla" (Rojas 60). Como en el poema de Rojas, pareciera haber en El regreso una elevación de la materia a lo sagrado. Y si Rojas señala que la única semilla que perdura es el sol (y por extensión el aire, tópico de su poesía) y todo lo demás muere, Barquero piensa en todo momento en la tierra y específicamente en la tierra campesina: en la tierra está la mesa, se asienta el árbol y caen los frutos, pero la semilla da frutos secretos. Postulamos que esa semilla es el símbolo de su creación poética como regeneración de una tradición cíclica en un mundo donde los elementos adquieren una significación de pertenencia.

\section{LA INFANCIA CLAUSURADA}

En conclusión, en este libro, Barquero, al hacer hablar a un niño, hace que este se configure ya no como objeto de enunciado, como había hecho hasta ahora, sino que como sujeto de enunciación. Es decir, mediado por la representación de un hablante que escribe desde la adultez, "libera" al niño de su condición subalterna, de su infancia muda y lo convierte en sujeto provisto de palabra, de razón e identidad, haciéndolo consciente de la temporalidad del ser humano. En este movimiento dialógico, la infancia sale de su silencio y se convierte en imagen representada, pero ahora mediante la voz de un niño. Este verbaliza, al final, las palabras que dan cuenta de su aprendizaje iniciático posterior al reconocimiento del sentido de la muerte de su padre y a la (per)vivencia del rito sacrificial, que clausura la infancia y da inicio a la adultez: "en la gran mesa de la tierra, todos somos a la vez / comensales y extraños frutos de los dioses" (88). Asimismo, en esta obra poética, el protagonismo del niño es reforzado no solo porque habla sino porque es el "portador" de la escena. Sin él, el rito no tendría sentido. Pareciera que la preocupación poética de Barquero tuviera, además, una finalidad antropológica de reconstrucción de una memoria, en donde se reúnen los utensilios necesarios de una existencia cotidiana fundante. En ese encuentro del pan, la piedra, la mesa, el agua y la tierra, la infancia tiene un espacio especial: es el lugar que, al hacerse consciente de su fin, posibilita no solo la vivencia del hogar, allí donde se encuentran padre, madre, abuelo, tía y que configuran una memoria de lo que se fue, de lo que se es y de lo que se pasa a ser; sino que también posibilita, 
en tanto portador de un cosmos fundado en el sacramento interno del hogar, que pervive y se intenta actualizar mediante la ritualización de la muerte del padre, la generación de un conocimiento nuevo, la vivencia de un niño que ha experimentado una instancia de aprendizaje vital, de crecimiento.

\section{BIBLIOGRAFÍA}

Azócar, Rafael. Cuando el alimento es el hombre. Un breve estudio de la antropofagia en el Nuevo Mundo. Tacna: Editorial Imprenta Alameda, 2005.

Barquero, Efraín. Antología. Santiago: LOM, 2000. El viejo y el niño. Santiago: Andrés Bello, 1992. El regreso. Santiago: Ed. Revista Atenea, 1961.

Davison, Omar. La casa como espacio de celebración en la poesía de Efraín Barquero. Tesis Magíster. P. Universidad Católica de Chile, 2005.

Dostoievski, Fiodor. Los hermanos Karamazov. 1880. Barcelona: Altaya, 1995.

Freud, Sigmund. "Dostoievski y el parricidio". Psicoanálisis del arte. 1928. Madrid: Alianza, 1985. 213-231. 1988.

"Tótem y tabú". Obras completas. 1913. Vol. 13. Buenos Aires: Amorrortu,

Grammatico, Giuseppina. "El descenso al Hades de Odiseo. Reflexiones a partir de una relectura de los libros X y XI de la Odisea". El descenso como itinerario del alma. Santiago: Universidad Metropolitana de Ciencias de la Educación, 1995. 63-72.

Homero. Odisea. Barcelona: Altaya, 1994.

Langer, Susanne. Nueva clave de la filosofía. Un estudio acerca del simbolismo de la razón, del rito y del arte. Buenos Aires: Sur, 1941.

Maeterlinck, Maurice. El pájaro azul. 1908. Buenos Aires: Losada, 1938.

Maldonado, Luis. La violencia de lo sagrado. 1973. Salamanca: Ediciones Sígueme, 1974.

Marchant, Patricio. Sobre árboles y madres. Santiago: Sociedad Editora Lead, 1984.

Matteo, Jorge. Efraín Barquero: "Una forma de habitar en el mundo" (Genealogía y síntesis de la primera parte de su obra). Tesis Licenciatura. U. de Chile, 2001.

Navarrete, Fabián. "La función dialéctica en El regreso de Efraín Barquero". Guerrero, Claudio, et al. Tres poetas de los años cincuenta: Teillier, Rubio y Barquero. Tesis Licenciatura. U. de Chile, 2000. 85-139.

Nómez, Naín. "La poesía de los cincuenta: aproximaciones a una modernidad en disolución". Taller de Letras 34 (2001): 85-96.

"En torno a la poesía de Efraín Barquero". Barquero, Efraín. Antología. Santiago: LOM, 2000. 5-21.

Antología crítica de la poesía chilena. 1996. Selección, introducción, notas y bibliografía del autor. Santiago: LOM, 2000. 
Paz, Octavio. Los hijos del limo. 1972. Santiago: Tajamar Editores, 2008.

Rojas, Gonzalo. La miseria del hombre. 1948. Valparaíso: U. de Playa Ancha, 1995.

Solotorevsky, Myrna. "Estética de la totalidad y estética de la fragmentación". Hispamérica 75 (1996): 17-36.

Warnken, Cristián. La belleza del pensar. Videograbación. Entrevista con Efraín Barquero. $56 \mathrm{~m}$. formato VHS, 2001. 